\title{
INCREASING HEAVY OIL RESERVES IN THE WILMINGTON OIL FIELD THROUGH ADVANCED RESERVOIR CHARACTERIZATION AND THERMAL PRODUCTION TECHNOLOGIES
}

Cooperative Agreement No.: $\quad$ DE-FC22-95BC14939

Contractor Names: $\quad$ City of Long Beach Department of Oil Properties (City) and Tidelands Oil Production Company (Tidelands), Long Beach, CA.

Date of Report: $\quad$ May 11, 1997

Award Date: $\quad$ March 30, 1995

Anticipated Completion Date: March 29, 1999

DOE Award:

$\$ 3,408,216$ (1995 Actual)

$\$ 837,301$ (1996 Actual)

Principal Investigator: $\quad$ Scott Hara - Tidelands

Program Manager: Jerry Casteel - Bartlesville Project Office

Reporting Period: $\quad$ October 1, 1996 to December 31, 1996 


\section{Objectives}

The project involves improving thermal recovery techniques in a slope and basin clastic (SBC) reservoir in the Wilmington field, Los Angeles Co., Calif. using advanced reservoir characterization and thermal production technologies.

The existing steamflood in the Tar zone of Fault Block (FB) II-A has been relatively inefficient because of several producibility problems which are common in SBC reservoirs. Inadequate characterization of the heterogeneous turbidite sands, high permeability thief zones, low gravity oil, and nonuniform distribution of remaining oil have all contributed to poor sweep efficiency, high steam-oil ratios, and early steam breakthrough. Operational problems related to steam breakthrough, high reservoir pressure, and unconsolidated formation sands have caused premature well and downhole equipment failures. In aggregate, these reservoir and operational constraints have resulted in increased operating costs and decreased recoverable reserves. The advanced technologies to be applied include:

(1) Develop three-dimensional (3-D) deterministic and stochastic geologic models.

(2) Develop 3-D deterministic and stochastic thermal reservoir simulation models to aid in reservoir management and subsequent development work.

(3) Develop computerized 3-D visualizations of the geologic and reservoir simulation models to aid in analysis.

(4) Perform detailed study on the geochemical interactions between the steam and the formation rock and fluids.

(5) Pilot steam injection and production via four new horizontal wells (2 producers and 2 injectors).

(6) Hot water alternating steam (WAS) drive pilot in the existing steam drive area to improve thermal efficiency.

(7) Installing a 2100 foot insulated, subsurface harbor channel crossing to supply steam to an island location.

(8) Test a novel alkaline steam completion technique to control well sanding problems and fluid entry profiles.

(9) Advanced reservoir management through computer-aided access to production and geologic data to integrate reservoir characterization, engineering, monitoring, and evaluation.

\section{Summary of Technical Progress}

This is the seventh quarterly technical progress report for the project. Through December 1996, project work related to well drilling and completion, surface facilities, and deterministic 3-D geologic modeling has been completed and reservoir characterization 
work is making good progress but is slightly behind schedule. Estimated costs are on budget for the work performed to date. Technical achievements accomplished during the quarter include placing the third and fourth horizontal wells on production following cyclic steam stimulation, completing a draft of the first DOE Annual Report, and kicking off an aggressive technical transfer program. Work is continuing on the stochastic geologic and reservoir simulation models. High temperature core work and reservoir tracer work will commence in the First Quarter 1997.

The project work completed to date comprises over $63 \%$ of the budgeted funds. Technology gained from these activities has been significant and the project team has embarked on a very aggressive and innovative program to transfer these new technologies. During this quarter, the project team had thirteen activities ${ }^{3-15}$ including a presentation at the 1996 SPE Annual Technical Meeting, four activities involving the West Coast Petroleum Technology Transfer Council (PTTC) workshops and meetings, one presentation at the local SPE monthly meeting, three articles in major newspapers, and four meetings requested by outside operators to present specific project-related technologies.

Two technologies being developed in this project are generating extraordinary interest from both independent and major oil companies. One technology is the 3-D geologic modeling work and how it has been applied cost effectively for identifying bypassed reserves and providing real-time control for directionally drilling horizontal wells ${ }^{2,18,19,27-30,34,40,46}$. The second technology is the novel low cost well completion technique using steam for formations with unconsolidated sands $8,14,23,43,44$. The project team has been requested to make several public and private presentations on these technologies. In the case of the 3-D modeling work, one vendor is featuring the Wilmington Field models in their advertising ${ }^{29,30}$.

\section{- Compilation and Analysis of Existing Data}

A computer database of production and injection data and previous reservoir studies was compiled for the FB II-A Tar zone. Digitized and normalized log data were completed for 171 wells (over 600 wells penetrate the Tar zone in the fault block). The digitized logs include the electric or induction and the spontaneous potential (SP) and/or gamma ray (GR). The log data from the 171 wells are distributed throughout the fault block and provide the base case log file for developing the 3-D stochastic geologic and reservoir simulation models. Another 100 logs will be digitized and normalized to use as "confirmation" logs for the stochastic modeling. Conventional cores throughout the zone were obtained from the previous operator in nine of the 171 wells which were used to correlate the formation rock and log data. 


\section{- Advanced Reservoir Characterization}

The basic reservoir engineering technical work, including several draft reports covering various aspects of the study, has been completed. The reports are entitled "Application of Basic Reservoir Engineering Techniques to the Tar Zone Fault Block IIA, Wilmington, CA"; "Study of Pre-1960 Well Logs in Fault Block IIA, WilmingtonField"; and "Study of Water Injection Surveys, Tar Zone Fault Block II, Wilmington Field". Historical problems with oil, gas, and water production allocations to each well and to each zone completed in the wells are evident in the material balance calculations. Work was performed on evaluating the aquifer for water influx and determining original oil in place by varying gas saturations to support the material balance work. Work completed includes an analysis of the primary and waterflood recoveries, permeability estimates from performance data, comparing water injection profile surveys to the allocated injection volumes for each sub-zone, determining the quality of the new and old well logs, determining the vertical communication between sands, and evaluating the aquifer and solution gas ${ }^{17,37}$.

A parametric study is proceeding on projected steam drive recoveries from vertical and horizontal wells using the TETRAD ${ }^{\mathrm{TM}}$ thermal reservoir simulator program, a product of Dyad 88 Software Inc. This study will compare recovery from both types of well completions as a function of reservoir properties, crude oil characteristics, and injection strategies and should be completed by June $1997^{41}$.

The tracer program has been delayed because the main hot water distribution line was temporarily disconnected to accomodate the surface landowner. Lab work has been completed to identify non-radioactive reservoir tracers effective in high temperature $\left(500^{\circ} \mathrm{F}\right)$ environments. The tracer program includes two tracers, ammonium thiocyanate and lithium chloride which will be bulk injected into the "T" and "D" zone in the WAS pilot injectors in the First Quarter 1997. The tracers will follow the liquid phase of the injected fluids rather than the steam phase. Computer software has been developed to map formation permeability in 3-D from production and injection data. The software has been tested using a compositional model at a major research company in California.

The high temperature core work has been delayed until lab procedures for measuring rock compaction due to steamflooding can be incorporated into the original proposal to perform steam pot tests and measure the geochemical effects of high temperature steam on the reservoir rocks and fluids. All of the special core work above will be used in the thermal reservoir simulation model. Lab work on the cores should commence in the First Quarter 1997.

A 3-D deterministic geologic model was completed which is being used to develop the 3-D stochastic geologic model and was used for drilling the observation and horizontal wells $^{2,18,19,27-30,34,40,46}$. The deterministic model correlates eighteen sand tops in the Tar 
zone. All existing cores were visually inspected and the core and log data were evaluated to develop a core-based log model, a porosity-permeability model and a rock-log mode $^{31,45}$. These models will provide the rock and reservoir data for the stochastic geologic model in locations where only well log data exists. A draft report entitled "RockLog Model Tar Zone (T and D Sands) Wilmington Field" was completed in October 1996.

Other deterministic geologic draft reports that have been completed include "Stratigraphic Equivalents of the Wilmington Field 'Tar Zone' in the Subsurface Los Angeles Basin, California"; and "Barrier Characteristics of the Geologic Faults". The first report provides information to the Los Angeles Basin oil producers regarding which reservoirs they operate are analogous to the Tar zone in the Wilmington field. The second report analyzes the possibility of fluid movement across faults using production and injection data and capillary transition and oil-water contact data ${ }^{28}$. This analysis is being used in the basic reservoir engineering and reservoir simulation modeling.

On the stochastic geologic model, the neural network analyzer is continuously being upgraded to analyze the similarities of various zones and sub-zones in terms of sequence stratigraphy using gamma ray, spontaneous potential, neutron, and resistivity logs and to improve signal compression through linear transform techniques such as DCT, Fourier Transform, and DST, 43 . Sample stochastic grid block models are test run on FB II-A logs using the 3-D Earth-Vision ${ }^{\mathrm{TM}}$ visualization software to ensure compatibility. We conducted a sand sequence analysis of the geologic column in the Tar Zone to map local effects requiring special correlation studies during the conceptual modeling phase. Of particular interest is whether log normalization and environmental correction work can significantly affect log character with regard to variogram modeling. Efforts are focused on examination of the rock types identified based on log and core data and the application of facies distribution and heterogeneity description using indicator modeling.

\section{- Reservoir Simulation}

The STARS ${ }^{\text {TM }}$ thermal reservoir simulation program by the Computer Modelling Group (CMG) of Calgary and the R10,000 Onyx RE2 work station by Silicon Graphics Incorporated (SGI) were selected for the stochastic modeling which began in October 1996. Preliminary history matches covering the primary depletion period have been completed utilizing both the CMG IMEX ${ }^{\mathrm{TM}}$ black oil simulator program and STARS for history match verification purposes. A CMG utility program was applied to transform black oil data in IMEX to compositional data in STARS, which shows reasonable results.

The project team developed a rock compaction algorithm to upgrade the one currently in the STARS program. The algorithm can mimic the local and dynamic features of rock compaction and rebound as a function of reservoir pressure. CMG is reviewing the algorithm for possible inclusion in STARS. 


\section{- Reservoir Management}

Four horizontal wells (two steam injectors and two producers) were drilled in late 1995 with measured depths of $4380-4820 \mathrm{ft}$ and $1700-2075 \mathrm{ft}$ of section in the target "D1" sands at a true vertical depth ranging from $2410-2660 \mathrm{ft}$. All of the wells were completed over the last $600 \mathrm{ft}$ of the horizontal section and given cyclic steam stimulation jobs in 1996 to consolidate the formation sands around the perforated completions ${ }^{8,14,23,43,44}$ and to stimulate initial oil production. The two injection wells, 2AT-61 and 2AT-63, were selectively completed with 11 quarter inch limited entry perforations per well and the two production wells, UP-955 and UP-956, were selectively completed with 48 and 36 quarter inch perforations, respectively, to provide more productivity and test the perforating limits of the sand consolidation process. The four wells initially would accept only low rates of about 300-500 barrels of cold water equivalent steam per day (BCWESPD) at 1300 psi injection pressure and 900 psi reservoir pressure which would increase to the desired rate of 1500 BCWESPD per well gradually over two months (process accelerated in two wells by breaking down the perforations with high pressure water).

Injection wells 2AT-61 and 2AT-63 were given cyclic steam stimulation jobs $(146,000$ and 186,000 bbls steam, respectively [corrected figures from previous quarterly report]) during the first half of 1996 and began producing in early Summer. Production results were mixed. Gross production rates ranged from 1200-1500 BPD/well compared to projected rates of 1500 BPD. Peak oil production rates ranged from 41-60 BPD/well compared to projected rates of $300 \mathrm{BPD} /$ well. The low oil production rates cannot be explained at this time. Well 2AT-61 was converted to injection in November and well 2AT63 will be converted to injection in January 1997. Of note is that both wells had no sand fill during pump replacement jobs, indicating successful sand consolidation jobs.

Production wells UP-955 and UP-956 were given cyclic steam stimulation jobs (114,000 and 183,000 bbls steam, respectively) during the second half of 1996. UP-955 was placed on production November 26 and reached 1250 BPD gross and 80 BPD oil by year end. UP-956 is in the steam soak phase and will be placed on production in January.

The $2100 \mathrm{ft}$ steam transmission line under the Cerritos Channel was placed in service in mid-December 1995 and has performed very well with no problems to date ${ }^{22}$.

Four existing steam injection wells were converted to hot water injection from March, 1995 to February 1996. Total hot water injection rates ranged from 500-3000 BWPD during this period. No incremental production response was observed. Hot water injection was discontinued and steam injection was resumed from February to November due to surface owner requirements to move the hot water injection lines. Hot water injection resumed in November at 4400 BWPD. The reservoir tracers will be injected into one "T" and one "D" injector in the First Quarter 1997. 
Detailed thin section, scanning electron microscope, and x-ray diffraction work on wellbore fill samples from the existing steam drive wells show several types of scale including calcites, dolomites, barites, anhydrites, and magnesium-silicates. A study of the cores, produced fluids, and injection water has been completed that determined the mineralogy and source of the scales and how to prevent their occurrence ${ }^{48}$.

The project team is continuing to find new ways to reduce steamflood operating costs. An improved $\mathrm{H}_{2} \mathrm{~S}$ caustic scrubber has been jointly developed by engineers from T. J. Cross Engineers and Tidelands Oil Production Company for stripping the $\mathrm{H}_{2} \mathrm{~S}$ from steamflood-related produced gas streams at less than half the previous cost. This new scrubber process, called Lo CoST ${ }^{\mathrm{SM}}$, improves the caustic mixing system and uses a more effective caustic substitute called SulfaTreat ${ }^{\mathrm{TM}}$ in the latter scrubber stages for removing low $\mathrm{H}_{2} \mathrm{~S}$ concentrations which results in significantly lower caustic usage $\mathrm{e}^{21,25,38}$. Operating cost reductions through vendor alliances and special electrical rates are in progress. Electrical power deregulation and innovative electricity rate schedules provide several means for resourceful operators to negotiate lower power costs. Power cost reduction projects can be taylored to be especially effective in allowing marginal wells to stay on production or to provide incentives to return idle wells to production ${ }^{42}$.

\section{- Operational Management}

Most of this work is dependent upon the results of the high temperature core work to be performed.

\section{- Technical Transfer}

Project work related to well drilling and completion, surface facilities, and deterministic 3-D geologic modeling has been completed. Technology gained from these activities has been significant and the project team has embarked on a very aggressive and innovative program to transfer these new technologies. The project team made presentations on the major activities completed and status of the project to representatives from the DOE Bartlesville Project Office on September 19 in Tidelands' office in Long Beach ${ }^{1}$. A magazine article was published in the September 1996 issue of The American Oil and Gas Reporter on how 3-D mapping and horizontal wells breathes new life into mature oil fields, which is specifically about this DOE Class III project ${ }^{2}$. During this quarter, the project team had thirteen activities ${ }^{3-15}$. Three articles in the Los Angeles Times were published during the quarter about the oil industry in the Los Angeles Basin with significant input from the project team members ${ }^{6,13,15}$. Four meetings were requested by operators to present specific project-related technologies $5,10,11,14$. A paper was presented at the 1996 SPE Annual Technical Meeting ${ }^{4}$ and a presentation was given at the local SPE monthly meeting ${ }^{3}$. The project team was involved in four activities related to West Coast Petroleum 
Technology Transfer Council workshops and meetings $\mathrm{s}^{7,8,9,12}$. The project team has committed to 32 activities during the next six months ${ }^{16-47}$. The innovative approach is the project team members' major involvement in the West Coast PTTC organization and the 1997 SPE Western Regional Meeting which has provided a multitude of technical transfer outlets for the DOE Class III projects ${ }^{7,12,16,36}$.

A home page is active on the Internet (http://www.usc.edu/peteng/doe.html) for the project. A draft CD-ROM of the project has been completed and is being reviewed for content and is available in Apple Macintosh format ${ }^{9,46}$. The CD-ROM is being revised to allow viewing on IBM PC format which should be available by June 1997.

\section{References and Notes}

1. The project team made presentations on the major activities completed and status of the project to representatives from the DOE Bartelsville Project Office on 19 September 1996 in Tidelands' office in Long Beach.

2. Phillips, C., Tidelands Oil Production Company,Clarke, D., City of Long Beach, An, L., University of Southern California: Article in September 1996 issue of The American Oil and Gas Reporter entitled "3-D Modeling, Horizontal Drilling...Give New Life To Aging Fields", pages 106-115.

3. Siegwein, S., Tidelands Oil Production Company: Oral presentation on "Review of Recent Well Drilling Activities by THUMS Long Beach Company and Tidelands Oil Production Company", Siegwein discussed DOE Tar Zone horizontal wells drilled and completed in Fault Block II and how we transfered technology to Tar Zone horizontal wells on Fault Block V, SPE Los Angeles Basin Environmental and Study Group Forum, Long Beach Petroleum Club, 25 September 1996.

4. Ershaghi, I.and Hassibi, M.: "A Neural Network Approach for Correlation Studies in a Complex Turbidite Sequence", SPE Paper No. 36720 presented at the 1996 SPE Annual Technical Conference in Denver, CO, 6-9 October.

5. Hara, S., Tidelands Oil Production Company: Discussed new technologies developed through DOE thermal and waterflood projects with Tom McCloskey of West Newport Oil Company, meeting in Long Beach, CA, 4 November 1996.

6. Clarke, D., Colazas X., City of Long Beach, Wiscombe J., Los Angeles Times: "Drilling in Disguise", Los Angeles Times, Metro Section, Page B2, 15 November 1996. Article describes oil production in the Long Beach Harbor and man-made oil production islands. 
7. Ershaghi, I., University of Southern California, Coordinator of the PTTC Problem Identification Workshop, held in Bakersfield (20 November 1996), Long Beach (25 November 1996), and Ventura (26 November 1996), CA.

8. Hara, S., Tidelands Oil Production Company: Oral presentation on "Novel Sand Consolidation Completion Technique Using Alkaline-Steam Injection in the Tar Zone, Wilmington Field", PTTC Problem Identification Workshop, held in Bakersfield (20 November 1996), Long Beach (25 November 1996), and Ventura (26 November 1996), CA.

9. Kapelke, M., Tidelands Oil Production Company: Oral presentation on "Multimedia and Technical Transfer", PTTC Problem Identification Workshop, held in Bakersfield (20 November 1996), Long Beach (25 November 1996), and Ventura (26 November 1996), CA.

10. Hara, S., Tidelands Oil Production Company: Discussed new technologies developed through DOE thermal and waterflood projects with Jaime Roig of Berry Petroleum Company, meeting in Bakersfield, CA, 19 November 1996.

11. Hara, S., Mondragon, J., Tidelands Oil Production Company: Discussed new technologies developed through DOE thermal and waterflood projects with Bryan Campbell, Greg Cave, and Moe Hanna, PanCanadian Petroleum Ltd. of Canada, meeting in Long Beach, CA, 3 December 1996.

12. Yang, Z. (Tar zone reservoir simulation on primary production), Akkutlu, Y. , Handy, L. (Tar zone reservoir material balance studies), An, L. (Geologic 3-D modeling), Du, C. (Stochastic reservoir modeling), Ershaghi, I. (Opening Ceremonies speaker), University of Southern California, Kapelke, M. (CD-ROM project), Tidelands Oil Production Company: Opening Ceremonies of West Coast PTTC Office, Facility tour included demonstrations by individuals above on latest technologies available in PTTC office, all based on work performed on this DOE project, held at the West Coast PTTC office on the USC campus, Los Angeles, CA, 6 December 1996.

13. Phillips, C., Tidelands Oil Production Company, Rose, P. P., freelance writer: "In Geological Time, He's Ancient", Los Angeles Times, Business Section, Page D5, 9 December 1996. Article describes petroleum geology as a career, the use of advanced technologies to maintain skills, and provides a personal profile on Chris Phillips.

14. Hara, S., Tidelands Oil Production Company: Discussed novel sand consolidation well completion technique developed through DOE thermal project with Darryl Luoma and Carl Montgomery, ARCO and Tim Brix, City of Long Beach, meeting in Long Beach, CA, 18 December 1996. 
15. Ershaghi, I., University of Southern California, Clifford, F., Los Angeles Times: "A New Oil Boom - Fledgling firms use technology to tap into reserves in abandoned wells and give new lease on life to a 19th century industry", Los Angeles Times, Metro Section, Page B2, 24 December 1996.

16. Ershaghi, I., University of Southern California, Clarke, D., City of Long Beach: Coordinators of the PTTC Focused Technology Workshop, "California Geology With and Without Computer Graphics", USC campus, Los Angeles, CA, 15 January 1997.

17. Ershaghi, I., University of Southern California: Oral presentation on "Geological Control on Reservoir Productivity", PTTC Workshop on California Geology With and Without Computer Graphics, USC campus, Los Angeles, CA, 15 Jan 1997

18. Clarke, D., City of Long Beach: Oral presentation on "New Ways To Do Geology", PTTC Workshop on California Geology With and Without Computer Graphics, USC campus, Los Angeles, CA, 15 Jan 1997

19. Phillips, C., Tidelands Oil Production Company, Clarke, D., City of Long Beach, An, L., University of Southern California: Oral presentation on "Case Histories - DOE Supported Projects, Thermal Flood, Tar Zone, Wilmington Oil Field", PTTC Workshop on California Geology With and Without Computer Graphics, USC campus, Los Angeles, CA, 15 Jan 1997.

20. Yang, Z., An, L., University of Southern California: Developed COMPACT software program to be incorporated as module into Computer Modelling Group's STARS thermal simulator program. COMPACT is an algorithm that can mimic the local and dynamic features of rock compaction and rebound as a function of reservoir pressure.

21. Cassinis, R., Massey, S., Tidelands Oil Production Company, Heisler, S. M., T. J. Cross Engineers, Inc.: "Improved $\mathrm{H}_{2} \mathrm{~S}$ Caustic Scrubber", to be presented at the 1997 8th Annual Energy Week Conference and Exhibition sponsored by API and ASME in Houston, TX, 30 January.

22. Cassinis, R., Tidelands Oil Production Company, et al: "2100-foot, 14-inch Steam Line Under a Ship Channel", SPE Paper No. 37530 presented at the 1997 SPE International Thermal Operations and Heavy Oil Symposium in Bakersfield, CA, 1012 February.

23. Hara, S., Tidelands Oil Production Company: Discussed novel sand consolidation well completion technique developed through DOE thermal project with John Horstkoetter, Mark Vandergon, and William Grames of BP Exploration (Alaska) Inc., 
Jim Spearman of BJ Services Company, and Dave Dillon of Centrilift Pumps, Inc., meeting in Long Beach, CA, 13 February 1997.

24. Ershaghi, I., University of Southern California, Tiedeman, H., DOE, Dutton, G., staff writer for Compressed Air Magazine: "Coaxing Crude From The Ground", Compressed Air Magazine, pages 22-26, March 1997. Article describes DOE Reservoir Class program and specifically describes Wilmington Thermal DOE project and Carpinteria DOE project.

25. The Sulfatreat Company, Cassinis, R., Massey, S., Tidelands Oil Production Company, Heisler, S. M., T. J. Cross Engineers, Inc.: "The Story Behind Lo CoST SM", Oil, Gas \& Petrochem Equipment Magazine, back cover page, March 1997. Advertisement by The Sulfatreat Company on product developed through DOE project work related to "Improved $\mathrm{H}_{2} \mathrm{~S}$ Caustic Scrubber" technology.

26. Al-Qahtani, M., Ershaghi, I., University of Southern California: "Characterization and Estimation of Permeability Correlation Structure from Performance Data", Paper presented at Fourth International Reservoir Characterization Technical Conference sponsored by DOE, BDM, and AAPG, 2-4 March 1997.

27. Clarke, D., City of Long Beach, Phillips, C., Tidelands Oil Production Company, An, L., University of Southern California: "Horizontal Wells in a Clastic Oil Field with Intraformational Compaction", Poster Session presentation at the 1997 AAPG Annual Meeting in Dallas, TX, 7-9 April.

28. An, L., Ershaghi, I., University of Southern California, Clarke, D., City of Long Beach, Phillips, C., Tidelands Oil Production Company: "Sealing Behavior of Normal Faults in Fault Block II, Wilmington Oil Field, California", Poster Session presentation at the 1997 AAPG Annual Meeting in Dallas, TX, 7-9 April.

29. Dynamic Graphics, Inc., Phillips, C., Tidelands Oil Production Company: "EarthVision Software Solutions for Structurally Consistent 3-D Geologic Modeling, 3-D Well Placement Planning", Advertisement Mailer sent to 1997 AAPG Annual Meeting (7-9 April) attendees which offers copy of September 1996 article from The American Oil and Gas Reporter entitled "3-D Modeling, Horizontal Drilling...Give New Life to Aging Fields" by Clarke, Phillips, An. Wilmington DOE projects featured in Dynamic Graphics' exhibit booth at convention and in Internet homepages (info@dgi.com and www.dgi.com/topko.html).

30. Schwalm, J., Perry, J., Dynamic Graphics, Inc.: "3-D Geologic Modeling: Theory and Application", 1/2 day workshop sponsored by PTTC at USC campus, Los Angeles, CA, 2 May 1997. Presentation will use 3-D deterministic geologic model from this project to explain fundamentals of 3-D geologic modeling. 
31. Davies, D. K., Vessell, R. K., David K. Davies and Associates, Inc.: "Geological Controls on Permeability Distribution and Sand Distribution: Tar Zone, Fault Block IIA, Wilmington Field", Oral presentation at the 1997 AAPG Pacific Section Convention in Bakersfield, CA, 14-16 May.

32. Clarke, D., City of Long Beach, Phillips, C., Tidelands Oil Production Company, An, L., University of Southern California: "Tertiary Development of Heavy Oil Sands Through Thermal Recovery in the Wilmington Field, California: An Update and Some New Challenges", Oral presentation at the 1997 AAPG Pacific Section Convention in Bakersfield, CA, 14-16 May.

33. Hassibi, M., Ershaghi, I., University of Southern California: "Characterization of Lithological Log Responses in Turbidite Series using Neural Networks", Oral presentation at the 1997 AAPG Pacific Section Convention in Bakersfield, CA, 1416 May.

34. An, L., University of Southern California, Clarke, D., City of Long Beach, Phillips, C., Tidelands Oil Production Company: "Reservoir Characterization Using Advanced 3-D Computer Modeling Technology: A Case Study of the Fault Block II in Wilmington Field, California", Electronic poster session at the 1997 AAPG Pacific Section Convention in Bakersfield, CA, 14-16 May.

35. Clarke, D., City of Long Beach: Project status presentation for DOE / BDM Conference regarding status of all DOE contracted projects, Houston, TX, 16-20 June.

36. Hara, P. S. (General Chairman), Wisdom, W. (Finance Chairman), Ehrman, J. (Arrangements Chairwoman), Frost, P. (Golf Tournament Chairman), Tidelands Oil Production Company, Blesener, J. (Registration Chairman), City of Long Beach, Davies, D. (Instructor [gratis to convention] of class on "Identification and Prevention of Formation Dameage through Detailed Rock Analysis"), David K. Davies and Associates, Ershaghi, I. (Instructor [gratis to convention] of class on "PTTC Intermediate Internet Training"), University of Southern California: 1997 SPE Western Regional Meeting in Long Beach, CA, 23-27 June. Significant time has been expended to promote the technical transfer of DOE Class III projects and other DOE activities at this convention including 14 Class III-related presentations or field trips ( 11 by Tidelands, the City of Long Beach, USC, and David K. Davies and Asssociates); distribution of a CD-ROM on the two City of Long Beach DOE projects at the DOE exhibit booth; the National Petroleum Technology Resource Center, an exhibit booth sponsored by DOE providing information on low cost resources available to operators; Alternative Dispute Resolution class sponsored by DOE; and a DOE panelist (Patricia Godley invited) on the Management Panel Session entitled E \& $P$ in the Western Region - Sunrise or Sunset? 
37. Ershaghi, I., Handy, L. L., Akkutlu, I. Y., University of Southern California, Mondragon III, J. J., Tidelands Oil Production Company: "Conceptual Model of FB IIA, Wilmington Field, from Field Performance Data", SPE Paper No. 38309 to be presented at the 1997 SPE Western Regional Meeting in Long Beach, CA, 25-27 June.

38. Cassinis, R., Tidelands Oil Production Company: "Improved $\mathrm{H}_{2} \mathrm{~S}$ Caustic Scrubber", SPE Paper No. 38273 to be presented at the 1997 SPE Western Regional Meeting in Long Beach, CA, 25-27 June.

39. Whitaker, W., Tidelands Oil Production Company: "7-ppm NO 50 MMBtu/hr Oilfield Steam Generator Operating on Low-Btu Produced Gas", SPE Paper No. 38277 to be presented at the 1997 SPE Western Regional Meeting in Long Beach, CA, 2527 June.

40. Phillips, C.C., Hara, P. S., Tidelands Oil Production Company: "Three-Dimensional Geological Modeling as a Cost-Effective Tool for Horizontal Drilling", SPE Gem Presentation No. WR GEM 6 to be presented at the 1997 SPE Western Regional Meeting in Long Beach, CA, 25-27 June.

41. Ershaghi, I., Amili, P., University of Southern California: "Correlations for Prediction of Steamflood Oil Recovery in Steam-Assisted Gravity-Drainage Process Using Horizontal Injectors and Producers", SPE Paper No. 38297 to be pesented at the 1997 SPE Western Regional Meeting in Long Beach, CA, 25-27 June.

42. Fickes, R., Tidelands Oil Production Company: "Enhancing the Profitability of Marginal Wells Through Vendor Alliances and Special Electrical Rates for Marginal Wells", SPE Gem Presentation No. WR GEM 27 to be presented at the 1997 SPE Western Regional Meeting in Long Beach, CA, 25-27 June.

43. Walker, F. S., Tidelands Oil Production Company: "Locating and Producing Bypassed Oil: A DOE Project Update", SPE Paper No. 38283 to be presented at the 1997 SPE Western Regional Meeting in Long Beach, CA, 25-27 June. This DOE waterflood project for Wilmington describes new application of well completion technology using steam to consolidate sand developed in this project.

44. Mondragon III, J. J., Hara, P. S., Tidelands Oil Production Company: "Novel Sand Consolidation Completion Technique Using Alkaline-Steam Injection in the Tar Zone, Wilmington Field", SPE Gem Presentation No. WR GEM 29 to be presented at the 1997 SPE Western Regional Meeting in Long Beach, CA, 25-27 June.

45. Davies, D. K., Vessell, R. K., David K. Davies and Associates, Inc.: "Improved Prediction of Permeability and Reservoir Quality Through Integrated Analysis of 
Pore Geometry and Openhole Logs: Tar Zone, Wilmington Field, California", SPE Paper No. 38262 to be presented at the 1997 SPE Western Regional Meeting in Long Beach, CA, 25-27 June.

46. Clarke, D., City of Long Beach, Phillips, C. C., Tidelands Oil Production Company, Ottot, G., Thums Long Beach Company: Field trip entitled "A Visit to the Giants of the Los Angeles Basin, Geology and Urban Operations in the L. A. Basin". A guidebook is to be provided consisting of fourteen papers on geologic and operational aspects related to slope and basin clastic reservoirs in the Los Angeles Basin. The field trip is to be given at the 1997 SPE Western Regional Meeting in Long Beach, CA, 25-27 June and is reprised from the field trip for the 1996 Annual Meeting of the American Association of Petroleum Geologists (AAPG) in San Diego.

47. Kapelke, M., Tidelands Oil Production Company: "How To Work With the DOE" and "Multimedia and Technical Transfer", National Petroleum Technology Resource Center sponsored by the DOE to be presented at the 1997 SPE Western Regional Meeting in Long Beach, CA, 25-27 June.

48. Davies,D. K., et al: Nature, Origin, Treatment and Control of Well-bore Scales in an Active Steamflood, Wilmington Field, California, SPE Paper No. 35418 presented at the SPE/DOE Improved Oil Recovery Symposium in Tulsa, OK, 21-24 April 1996. 
May 12, 1997

Mr. Jerry Casteel

Project Manager

U. S. Department of Energy

Bartlesville Project Office

P. O. Box 1398

Bartlesville, OK 74005

Subject: $\quad$ Quarterly Technical Progress Reports and Annual Report Status - Class III MidTerm Project, "Increasing Heavy Oil Reserves in the Wilmington Oil Field Through Advanced Reservoir Characterization and Thermal Production Technologies", DE-FC22-95BC14939.

Dear Jerry:

Attached are copies of our Quarterly Reports dated October 1 - December 31, 1996 and January 1 March 31, 1997 for the subject project and a floppy disk with the text in Adobe Acrobat. We sent the required copies to Pittsburgh today.

The final version of the first Annual Report for the period March 30, 1995 to March 31, 1996, which has been reviewed and edited by your office, will be submitted to Pittsburgh this month.

For your information, we have requested approval from Pittsburgh for submission of the second Annual Report for the period April 1, 1996 to March 31, 1997 in late July or early August. As you know, the entire project team has been very heavily involved in technical transfer activities related to this project since September 1996 as referenced in the Quarterly reports. This heavy technical transfer involvement will end during the last week of June after the 1997 Society of Petroleum Engineers Western Regional Meeting in Long Beach, of which I am the General Chairman. The second Annual Report will include all of the papers and exhibits presented through June. We are counting on your support for the time extension.

Unfortunately, I will not be able to attend the DOE / BDM Meeting from June 16-20 in Houston due to my commitment as General Chairman of the 1997 SPE Western Regional Meeting which takes place the following week. Don Clarke from the City of Long Beach will be attending the meeting and giving the presentation on our project status in my place. I'll be looking forward to seeing you at the 1997 SPE Western Regional Meeting!

Sincerely,

Scott Hara

Chief Production Engineer

PSH:DOE\STCOM397.FRM 